\title{
Norm Entrepreneurship and Diffusion 'From Below' in International Organisations: How the competent performance of vulnerability generates benefits for small states
}

Jack Corbett, University of Southampton, UK j.corbett@soton.ac.uk

$\mathrm{Xu}$, Yi-chong,

Patrick Weller,

\section{Abstract}

For decades, the world's smallest states - the structurally weakest members of the multilateral system-have been considered incapable of influencing international organisations (IOs). So, why has the label small state risen to prominence over the last two decades and become institutionalised as a formal grouping in multiple IOs? Drawing on more than 80 in-depth interviews, we explain the rise of Small Island Developing States in the United Nations system, the expansion of their agenda to the Small and Vulnerable Economies group at the World Trade Organization, and then to other IOs. The adoption of the labels is evidence of small state norm diffusion. We identify the competent performance of vulnerability within multilateral settings as the key to explaining this norm emergence and diffusion. The lesson is that diffusion 'from below' is not always driven by a desire to increase rank. In this case small states have gained benefits by maintaining a lowly position in a hierarchy in which large is stronger than small.

Keywords: norm entrepreneurs; norm diffusion; hierarchy; international organisations; small states; SIDS

Acknowledgements: This work was supported by the Australian Research Council (grant number DP160100897). The authors would like to thank Melodie Rewut for outstanding research assistance, and Jason Sharman, Jonathan Havercroft, the PACE crew, and four anonymous reviewers for helpful comments on an earlier version of this piece. 


\section{Norm Entrepreneurship and Diffusion 'From Below' in International Organisations: How the competent performance of vulnerability generates benefits for small states}

Why has 'small state', or 'small island developing state' (SIDS), become a label and an established grouping in the United Nations (UN) system over the last two decades when the countries it describes are defined by their vulnerability in a hierarchical order in which large is stronger than small? And, having established themselves at the UN, why have similar labels and groupings of small states emerged in other international organisations (IOs), like Small and Vulnerable Economies (SVEs) at the WTO, when forums such as the G20 and G7 explicitly seek to marginalise them? This recent development is hard to explain with traditional accounts of the exercise of power between member states in IOs. Of the dominant paradigms, constructivist accounts have the greatest potential, with a small but important body of scholarship on European small states highlighting how they are able to accentuate the positive features of smallness - 'innovative', 'active' and 'smart' - to exert influence that is disproportionate to their size and in doing so increase their 'status' ${ }^{1}$ or rank in the hierarchical order in which large is stronger than small. ${ }^{2}$ By contrast, in this case diffusion has not only emerged 'from below' ${ }^{3}$, championed by the structurally weakest members of the international system, but SIDS and SVEs have sought benefits by moving down, rather than up, the hierarchy in which large is stronger than small. We therefore extend existing studies by showing how these states have creatively exploited existing hierarchies in IOs by accentuating their vulnerability.

\footnotetext{
${ }^{1}$ Benjamin de Carvalho, and Iver B. Neumann (eds), Small states and status seeking: Norway's quest for international standing, (London and New York: Routledge, 2015). ${ }^{2}$ Annica Kronsell, 'Can Small States Influence EU Norms?: Insights from Sweden's participation in the field of environmental politics', Scandinavian Studies, 74:3 (2002), pp. 287-304; Christine Ingebritsen, 'Norm entrepreneurs: Scandinavia's role in world politics', Cooperation and Conflict, 37:1 (2002), pp. 11-23; Christopher S. Browning, 'Small, smart and salient? Rethinking identity in the small states literature', Cambridge Review of International Affairs, 19:4 (2006), pp. 669-84.

${ }^{3}$ Ann E. Towns, 'Norms and social hierarchies: understanding international policy diffusion "from below"', International Organization, 66:2 (2012), pp. 179-209; Ann E. Towns, Women and states: Norms and hierarchies in international society, (Cambridge: Cambridge University Press, 2010).
} 
This article thus seeks to explain how the smallest and weakest members of IOs have become 'norm entrepreneurs ${ }^{4}$ by emphasising their unique vulnerability in a hierarchical order in which large is stronger than small. Compared to poorer but larger states, ${ }^{5}$ SIDS and SVEs claim to enduring vulnerability is based on their: 1) ongoing struggle with diseconomies of scale resulting from the fact that they have a narrow export base (usually a combination of tourism, financial services and fisheries) that is uniquely vulnerable to global economic fluctuations; 2 ) that they are caught in a 'middle income trap' that sees them receive few of the concessions and development assistance of the very poorest countries, while having little prospect of becoming advanced industrialised nations; and 3) are often crippled by high levels of indebtedness as they need to regularly rebuild after extreme weather events; a cycle that will increase with climate change. To be sure, the group is diverse: many of these states are small islands, some Pacific SIDS receiving considerable development assistance, and some are land locked small states that experience few natural disasters. ${ }^{6}$ But the general appeal is commonly made on behalf of the group nonetheless.

We follow Katzenstein's", definition of norms as "social standards for the proper behaviour of actors of a stipulated identity". The constitutive norm ${ }^{8}$ that the states we now call SIDS and SVEs have championed is 'differentiated development': there is no one-size-fits all growth model and so for the states we now call SIDS and SVEs to pursue their right to development IOs need to differentiate between types of developing states, defined by their

\footnotetext{
${ }^{4}$ Martha Finnemore and Kathryn Sikkink, 'International norm dynamics and political change', International organization 52:4 (1998), pp. 887-917.

${ }^{5}$ See Cédric Jourde, 'The international relations of small neoauthoritarian states: Islamism, warlordism, and the framing of stability', International Studies Quarterly, 51:2 (2007), pp. 481-503; Donna Lee, 'African agency in global trade governance', in William Brown and Sophie Harman (eds.), African agency in international politics, (London: Routledge, 2013), pp. 44-48, ch. 3; and J.A Laker, African Participation at the World Trade Organisation, (Leiden: Martinus Nijhoff, 2014).

6 William Vlcek, Offshore finance and small states: Sovereignty, size and money, (London: Palgrave Macmillan, 2008); Matthew Louis Bishop, 'The political economy of small states: Enduring vulnerability?', Review of International Political Economy, 19:5 (2012), pp. 942960; John Connell, Islands at risk?: environments, economies and contemporary change, (Cheltenham: Edward Elgar Publishing, 2013) 7 Peter J. Katzenstein (ed.), The culture of national security: Norms and identity in world politics, (New York: Columbia University Press, 1996), p. 5.
}

8 Finnemore and Sikkink (1998) 
unique structural conditions, in order to maintain the principle of sovereign equality. This argument is buttressed by the observation that the current definition of development used by IOs includes everyone from the BRICS to the tiny Pacific Island state of Tuvalu (population $10,000)$, thus disadvantaging their smallest members. The evidence that this norm entrepreneurship has been persuasive is the creation of groupings like SIDS and SVEs in IOs - these groups would not exist unless IOs recognised the unique vulnerability of these states and by extension the principle of differentiated development (see Table 1). As Wiener (2014) argues, ${ }^{9}$ constitutive norms both reflect and create new categories of actors and actions, identities and interests in specific contexts. In turn, SIDS and SVEs have used recognition of their vulnerability to gain benefits. In process terms, the labels and the groupings they represent have changed the operation of IOs by allowing SIDS and SVEs to:

1. Create working groups, convene conferences and taskforces, and initiate reports and declarations, and secure work programs, that draw attention to their unique needs (i.e. Declaration of Barbados or the SAMOA Pathway);

2. Gain entry to key decision-making arenas (i.e. WTO Green Room)

3. Win positions on boards and key committees (i.e. Clean Development Mechanism; Adaptation Fund; and the Green Climate Fund)

4. Gain subsidies for their participation in 10 activities (i.e. the LDC/SIDS Trust Fund at the HRC or the Commonwealth Secretariat Small States Office in New York and Geneva)

This has further pluralized the decision-making of IOs. In policy terms, the label has resulted in SIDS and SVEs:

1. Providing leadership in decades of climate negotiations. They have not acted alone and they have had considerable technical support from NGOs, but they have unequivocally been key participants in the process, usually via the Alliance of Small Island States (AOSIS), and this has resulted in, for example, SDGs on Oceans and Climate; the 2017 UN Ocean Conference and appointment of former Permanent 
Representative to the UN for Fiji, Peter Thomson, as UN Special Envoy for the Ocean; and the 2018 UN Security Council debate on climate change (2014 was even the International Year of the Small Island Developing State).

2. Becoming a potential veto player across IOs. At the WTO, for example, the SVEs could insist they had a dedicated work program as part of the Doha Round in the knowledge that their interest could not be just ignored in a process that required consensus. The WTO Committee on Trade and Development now meets regularly to discuss and review their work programme;

3. Convincing the World Bank and IMF to change the way they think about the types of lending they provide and projects they finance. That is, rather than off the shelf solutions interventions are increasingly tailored to the scalar dynamics of development in SIDS and SVEs; and

4. Generating increased attention from IOs that had previously shown little interest: i.e. WIPO/WHO.

This influence has resulted in SIDS and SVEs either gaining trade concessions, access to concessional finance or development assistance (or veto existing concessions being taken away or graduation delayed). It has also advanced progressive action on climate change. These lists are not exhaustive and SIDS have not had it all their own way. ${ }^{10}$ Moreover, these successes would pale in significance if SIDS in particular were able to win compensation for the disproportionate impact of climate change, which in many respects is the holy grail of the vulnerability claim.

Caveats aside, these successes do illustrate that the label, and by extension the competent performance of vulnerability in the processes of IOs, are a key means by which maintaining a lowly rank in a hierarchy in which large is stronger than small can lead to diffusion 'from below' ${ }^{11}$ The competent performance of vulnerability has three characteristics: 1)

${ }^{10}$ e.g. Jackson (2012) on Antigua and Barbuda's case against the US in the WTO.

11 Towns (2010, 2012) 
'rhetorical action', 12 following the justifications outlined above; 2 ) collaboration or 'coalition building ${ }^{13}$ among SIDS and SVEs to act as veto players on key decisions; and 3) active participation as a distinct grouping in the processes and everyday practices of 10 s. ${ }^{14}$ This agenda has been aided by the practice of consensus in multilateral institutions, the ability of SIDS and SVEs to use their weight (numbers) to threaten vetoes, and their voting power in leadership elections. But each procedural feature is contingent on presence, something that cannot be assumed for SIDS and SVEs who suffer from well-documented capacity deficits. ${ }^{15}$ In short, to explain why the label has assumed prominence we have to analyse how these countries have engaged, individually and collectively, in the processes of IOs.

\footnotetext{
${ }^{12}$ Frank Schimmelfennig, 'The community trap: Liberal norms, rhetorical action, and the eastern enlargement of the European Union,' International organization, 55:1, (2001), pp.
} 47-8

13 Nicole Deitelhoff and Linda Wallbott, 'Beyond soft balancing: Small states and coalitionbuilding in the ICC and climate negotiations', Cambridge Review of International Affairs 25:3 (2012), pp. 345-66; Diana Panke, 'Dwarfs in international negotiations: how small states make their voices heard' Cambridge Review of International Affairs, 25:3 (2012b), pp. 31328.

14 Cf. Panke (2012a); Corbett, Jack, Xu Yi-Chong, and Patrick Weller. "Climate Change and the Active Participation of Small States in International Organisations." The Round Table 107.1 (2018): 103-105.

15 Joanne Wallis "Friendly islands" in an unfriendly system: Examining the process of Tonga's WTO accession', Asia Pacific Viewpoint, 51:3 (2010), pp. 262-77; Corbett, Jack, and John Connell. "All the world is a stage: global governance, human resources, and the 'problem' of smallness." The Pacific Review 28.3 (2015), pp. 435-459 
Table 1: Small State Groupings in IOs

\begin{tabular}{|c|c|c|c|c|c|c|c|}
\hline Organisation & $\begin{array}{l}\text { United Nations } \\
\text { (Small Island } \\
\text { Developing States) }\end{array}$ & $\begin{array}{l}\text { United Nations } \\
\text { (Alliance of } \\
\text { Small Island } \\
\text { States) }\end{array}$ & $\begin{array}{l}\text { United Nations } \\
\text { (Forum of Small } \\
\text { States) }\end{array}$ & $\begin{array}{l}\text { The } \\
\text { Commonwealth } \\
\text { Secretariat }\end{array}$ & $\begin{array}{l}\text { World Bank } \\
\text { (Small States } \\
\text { Forum) }\end{array}$ & $\begin{array}{l}\text { World Trade } \\
\text { Organization (Small } \\
\text { and Vulnerable } \\
\text { Economies) }\end{array}$ & $\begin{array}{l}\text { World Health } \\
\text { Organisation } \\
\text { (Small Countries } \\
\text { Initiative) }\end{array}$ \\
\hline Definition & $\begin{array}{l}\text { Est. } 1992 \text { at the Rio } \\
\text { Earth Summit. } \\
\text { Defined as } \\
\text { developing } \\
\text { countries facing } \\
\text { specific social, } \\
\text { economic and } \\
\text { environmental } \\
\text { vulnerabilities. } 38 \\
\text { are UN members } \\
\text { and } 14 \text { are non-UN } \\
\text { Members or } \\
\text { Associate } \\
\text { Members of the } \\
\text { Regional } \\
\text { Commissions. }\end{array}$ & $\begin{array}{l}\text { Est. 1990. An ad } \\
\text { hoc negotiating } \\
\text { body } \\
\text { established by } \\
\text { SIDS at the } \\
\text { United Nations. } \\
\text { 44 States and } \\
\text { observers }\end{array}$ & $\begin{array}{l}\text { Est. } 1992 \text { by } \\
\text { Singapore. } \\
\text { Informal group } \\
\text { for countries } \\
\text { with } \\
\text { populations of } \\
\text { less than } 10 \\
\text { million. }\end{array}$ & $\begin{array}{l}\text { Est. } 1997 \text { (but } \\
\text { first designated } \\
\text { in } 1977 \text { and } \\
\text { initially defined } \\
\text { in 1985). } 31 \\
\text { Commonwealth } \\
\text { members with a } \\
\text { population size } \\
\text { of } 1.5 \text { million } \\
\text { people or less } \\
\text { and larger } \\
\text { member states } \\
\text { that share } \\
\text { similar } \\
\text { characteristics } \\
\text { with them. }\end{array}$ & $\begin{array}{l}\text { Est. } 2000 \text {. The } \\
\text { Bank defines } \\
\text { small states as } \\
\text { countries that: } \\
\text { (a) have a } \\
\text { population of } \\
1.5 \text { million or } \\
\text { less; or (b) are } \\
\text { members of } \\
\text { the Small State } \\
\text { Forum (SSF). } \\
\text { The SSF } \\
\text { currently has } \\
50 \text { members. }\end{array}$ & $\begin{array}{l}\text { Est. } 2001 \text { as part of } \\
\text { the Doha } \\
\text { Declaration. SVEs } \\
\text { are defined as WTO } \\
\text { members that } \\
\text { account for a small } \\
\text { fraction of world } \\
\text { trade and are } \\
\text { particularly } \\
\text { vulnerable to } \\
\text { economic } \\
\text { uncertainties and } \\
\text { environmental } \\
\text { shocks but do not } \\
\text { qualify as LDCs. The } \\
\text { SVEs has } 26 \\
\text { members. }\end{array}$ & $\begin{array}{l}\text { Est. in } 2013 \text { at an } \\
\text { informal meeting } \\
\text { in Turkey. The } \\
\text { group comprises } 8 \\
\text { countries in the } \\
\text { WHO European } \\
\text { Region with a } \\
\text { population of less } \\
\text { than } 1 \text { million } \\
\text { people. }\end{array}$ \\
\hline
\end{tabular}




\begin{tabular}{|c|c|c|c|c|c|c|c|}
\hline Members & $\begin{array}{l}\text { UN Members: } \\
\text { Antigua and } \\
\text { Barbuda, Bahamas, } \\
\text { Bahrain, Barbados, } \\
\text { Belize, Cape Verde, } \\
\text { Comoros*, Cuba, } \\
\text { Dominica, } \\
\text { Dominican } \\
\text { Republic, Fiji, } \\
\text { Grenada, Guinea- } \\
\text { Bissau*, Guyana, } \\
\text { Haiti*, Jamaica, } \\
\text { Kiribati*, } \\
\text { Maldives*, } \\
\text { Marshall Islands, } \\
\text { Federated States of } \\
\text { Micronesia, } \\
\text { Mauritius, Nauru, } \\
\text { Palau, Papua New } \\
\text { Guinea, Samoa*, } \\
\text { São Tomé and } \\
\text { Príncipe*, } \\
\text { Singapore, St. Kitts } \\
\text { and Nevis, St. } \\
\text { Lucia, St. Vincent } \\
\text { and the } \\
\text { Grenadines, } \\
\text { Seychelles, } \\
\text { Solomon Islands*, } \\
\text { Suriname, Timor- }\end{array}$ & $\begin{array}{l}\text { Members: } \\
\text { Antigua and } \\
\text { Barbuda, } \\
\text { Bahamas, } \\
\text { Barbados, } \\
\text { Belize, Cape } \\
\text { Verde, } \\
\text { Comoros, Cook } \\
\text { Islands, Cuba, } \\
\text { Dominica, } \\
\text { Dominican } \\
\text { Republic, Fiji, } \\
\text { Federated } \\
\text { States of } \\
\text { Micronesia, } \\
\text { Grenada, } \\
\text { Guinea-Bissau, } \\
\text { Guyana, Haiti, } \\
\text { Jamaica, } \\
\text { Kiribati, } \\
\text { Maldives, } \\
\text { Marshall } \\
\text { Islands, } \\
\text { Mauritius, } \\
\text { Nauru, Niue, } \\
\text { Palau, Papua } \\
\text { New Guinea, } \\
\text { Samoa, } \\
\text { Singapore, } \\
\text { Seychelles, Sao } \\
\end{array}$ & $\begin{array}{l}\text { Members: More } \\
\text { than } 100\end{array}$ & $\begin{array}{l}\text { Members: } \\
\text { Antigua and } \\
\text { Barbuda, The } \\
\text { Bahamas, } \\
\text { Barbados, } \\
\text { Belize, } \\
\text { Botswana, } \\
\text { Brunei } \\
\text { Darussalam, } \\
\text { Cyprus, } \\
\text { Dominica, Fiji, } \\
\text { Grenada, } \\
\text { Guyana, } \\
\text { Jamaica, } \\
\text { Kiribati, } \\
\text { Lesotho, } \\
\text { Mauritius, } \\
\text { Namibia, } \\
\text { Maldives, Malta, } \\
\text { Nauru, Papua } \\
\text { New Guinea, } \\
\text { Samoa, } \\
\text { Seychelles, } \\
\text { Singapore, } \\
\text { Solomon } \\
\text { Islands, St Kitts } \\
\text { and Nevis, St } \\
\text { Lucia, St Vincent } \\
\text { and the } \\
\text { Grenadines, }\end{array}$ & $\begin{array}{l}\text { Members: } \\
\text { Antigua and } \\
\text { Barbuda, The } \\
\text { Bahamas, } \\
\text { Bahrain, } \\
\text { Barbados, } \\
\text { Belize, Bhutan, } \\
\text { Botswana, } \\
\text { Brunei } \\
\text { Darussalam, } \\
\text { Cabo Verde, } \\
\text { Comoros, } \\
\text { Cyprus, } \\
\text { Djibouti, } \\
\text { Dominica, } \\
\text { Equatorial } \\
\text { Guinea, } \\
\text { Estonia, Fiji, } \\
\text { Gabon, The } \\
\text { Gambia, } \\
\text { Grenada, } \\
\text { Guinea-Bissau, } \\
\text { Guyana, } \\
\text { Iceland, } \\
\text { Jamaica, } \\
\text { Kiribati, } \\
\text { Lesotho, } \\
\text { Maldives, } \\
\text { Malta, } \\
\text { Marshall } \\
\end{array}$ & $\begin{array}{l}\text { Members: } \\
\text { Antigua and } \\
\text { Barbuda, Barbados, } \\
\text { Belize, Bolivia, Cuba, } \\
\text { Dominica, } \\
\text { Dominican Republic, } \\
\text { El Salvador, Ecuador, } \\
\text { Fiji, Grenada, } \\
\text { Guatemala, } \\
\text { Honduras, Jamaica, } \\
\text { Mauritania, } \\
\text { Nicaragua, Panama, } \\
\text { Papua New Guinea, } \\
\text { Saint Kitts and Nevis, } \\
\text { Saint Lucia, Saint } \\
\text { Vincent and the } \\
\text { Grenadines, Samoa, } \\
\text { Seychelles, Sri } \\
\text { Lanka, Tonga, } \\
\text { Trinidad and Tobago }\end{array}$ & $\begin{array}{l}\text { Members: } \\
\text { Andorra, Cyprus, } \\
\text { Iceland, } \\
\text { Luxembourg, } \\
\text { Malta, Monaco, } \\
\text { Montenegro, San } \\
\text { Marino }\end{array}$ \\
\hline
\end{tabular}




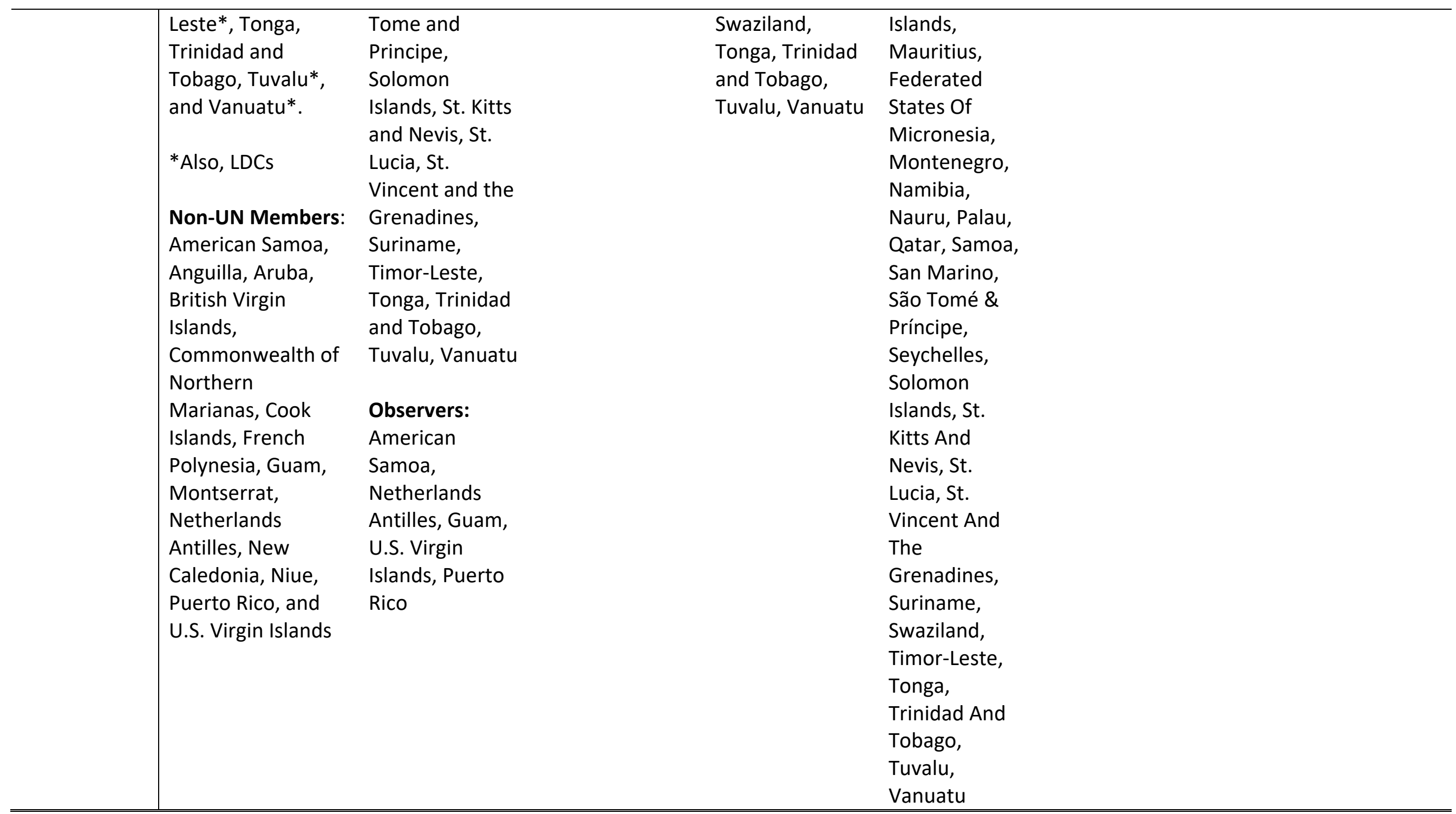


The implications of this argument are threefold:

Conceptually, we add to the existing literature on the mechanisms that drive norm emergence and diffusion in the multilateral system, which have thus far focused on powerful states, IOs or NGOs as the key agents of change, by showing how the smallest and weakest members can act as norm entrepreneurs. The acceptance and spread of the small state label is evidence of their persuasiveness and so we focus on how it has been achieved. We therefore contribute to recent scholarship ${ }^{16}$ on the survival of small states under anarchy by illustrating that the international regime of norms can lead to situations where smallness becomes an asset that delivers benefits. In doing so we add to the literature on diffusion 'from below' ${ }^{17}$ by highlighting that states can gain benefits by moving down, rather than up, a hierarchical order in which larger is stronger than small.

Methodologically, we augment existing accounts of why norm diffusion typically occursusually: learning, emulation, and competition ${ }^{18}$-by employing an interpretive approach that forgrounds everyday practices and processes within institutionalised settings. Specifically, we show how SIDS and SVEs have drawn on established norms-the right to development and the sovereign equality of states-to illustrate that existing definitions of development are too narrow and that differentiation between types of developing states, defined by their unique structural conditions, is necessary to protect their interests. In doing so they have created a constitutive norm based on the idea of 'differentiated development', despite resistance from larger states; and

Empirically, we add to the small number of qualitative studies on norm diffusion in IOs by providing an in-depth historical account of the emergence and diffusion of the small state

\footnotetext{
${ }^{16}$ Jason C. Sharman, 'War, selection, and micro-states: Economic and sociological perspectives on the international system', European Journal of International Relations 21.1 (2015), pp. 194-214; Jason C. Sharman, 'Sovereignty at the Extremes: Micro-States in World Politics,' Political Studies, 65:3 (2017), pp. 559-75

17 Towns $(2010,2012)$

18 Martino Maggetti and Fabrizio Gilardi, 'Problems (and solutions) in the measurement of policy diffusion mechanisms', Journal of Public Policy, 36:1 (2016), 87-107
} 
label based on more than 80 interviews, conducted with ambassadors and international civil servants in Geneva, New York, and selected SIDS and SVEs, combined with documentary research.

As we substantiate these claims we make no effort to define a 'small state'. The number of states has risen dramatically since the Second World War, with the UN's membership rising from 51 in 1945 to 193 today. Despite the world population having doubled in this same period, the trend towards more states means that the average size of the state has shrunk. ${ }^{19}$ Many of these new states have small populations. More than 100 have populations of less than 10 million; 39 have populations of less than 1 million. One consequence of this trend is that regardless of the definition used, the number of states that can be thought of as 'small' has steadily grown in recent decades. They have also become increasingly active participants in the multilateral system.

Since the 1950s, there has been an academic debate seeking to make sense of the participation of small and weak states in IOs. ${ }^{20}$ Typically, size is measured on the basis of either population, territory, economy, or military capabilities (or a combination of these factors). IOs meanwhile have their own definitions-embedded in the formal rules and informal practices - which the states we now call SIDS and SVEs have created to gain recognition and influence. So, we treat the definition as an empirical question and ask: when IOs talk about 'small states', who are they talking about and why have they created the definition that they have? Our claim is that the fact that IOs have defined SIDS and SVES demonstrates the capacity of these states to act as norm entrepreneurs and illustrates the tacit acceptance of 'differentiated development' as a constitutive norm. Any analysis of the

19 David Lake and Angela O'Mahony. 'The incredible shrinking state: Explaining change in the territorial size of countries', Journal of Conflict Resolution, 48:5 (2004), 699-722 20 For review, see Tom Crowards, 'Defining the category of "small" states', Journal of International Development 14:2 (2002), pp. 143-79; Paul Sutton, 'The concept of small states in the international political economy', The round table 100:413 (2011), pp. 141-53; and Matthew Louis Bishop, 'The political economy of small states: Enduring vulnerability?', Review of International Political Economy 19:5 (2012), pp. 942-60 
impact of SIDS and SVEs in IOs must therefore pay attention to how perceived size ${ }^{21}$ is constituted by collective processes.

This article unfolds over the following sections. First, we offer a brief summary of the importance of groupings and labels in multilateral diplomacy by reference to existing work on small states. Second, we situate our study by reference of Towns's work on norms diffusion 'from below'. Third, we discuss the approach and dataset we used to empirically verify these claims. Fourth, we narrate a history of how the SIDS and SVEs label has spread throughout the multilateral sphere focusing on the three characteristics of their performance. In the conclusion, we return to our argument that the key to explaining the diffusion of the small state label across IOs is the competent performance of vulnerability within multilateral settings.

\section{Small States, Multilateralism, Groupings and Labels}

Norms scholars typically explain the cycle 22 of emergence and diffusion as being driven by either coercive large states, the secretariat of IOs, or transnational advocacy networks. ${ }^{23}$ In this literature small states are largely absent, with the traditional arguments are taken as given: that small states participated in IOs only when 'America's crusading spirit presented small allies with bargaining influence' ${ }^{24}$ or when large states allowed them 'to act

21. Matthias Maass, 'The elusive definition of the small state', International politics, $46: 1$ (2009), pp. 65-83; cf Tom Long, 'It's not the size, it's the relationship: from "small states" to asymmetry', International Politics, 54:2 (2017), 144-60.

22. Finnemore and Sikkink (1998); Ann Florini, 'The evolution of international norms', International Studies Quarterly, 40:3 (1996), 363-89.

23 Martha Finnemore, 'International organizations as teachers of norms: the United Nations Educational, Scientific, and Cultural Organization and science policy', International Organization, 47:4 (1993), 565-97; Margaret E. Keck and Kathryn Sikkink, 'Transnational advocacy networks in international and regional politics', International Social Science Journal, 51:159 (1999), pp. 89-101; Susan Park, 'Norm diffusion within international organizations: a case study of the World Bank', Journal of International Relations and Development, 8:2 (2005), pp. 111-41; and R. Charli Carpenter, 'Setting the advocacy agenda: Theorizing issue emergence and nonemergence in transnational advocacy networks', International Studies Quarterly, 51:1 (2007), pp. 99-120.

${ }^{24}$ Robert O. Keohane, 'The big influence of small allies', Foreign Policy, 2 (1971), p. 173. 
collectively to help shape developing international attitudes, dogmas, and codes of proper behaviour'. ${ }^{25}$

There is a small but important body of work that contests this conventional account by showing that some small states, and those in Europe in particular, are an exception to this trend, at least on certain issues and in certain IOs. ${ }^{26}$ Specifically, this work has focused on how small states overcome structural weaknesses via adaptive strategies, including agenda setting, issue prioritization and coalition building. We build on this work in our empirical section below but also extend it by focusing on SIDS and SVEs. By focusing on non-European states we also contribute to the literature on small state resilience, which is primarily dominated by economists interested in technical means by which these poorer small states can better cope with exogenous shocks. ${ }^{27}$ Common to both sets of studies, however, is a belief that small states have sought to counter the perception they are vulnerable by adopting 'the typical features of a sovereign state, despite radical diseconomies of scale, largely on symbolic grounds, which may provide incidental benefits'. ${ }^{28}$

Securing social acceptance through conformity to promote legitimacy may explain why small states exist but it requires a much more radical departure from mainstream IR theories about sovereignty and statehood to claim that they might thrive and even alter the institutional practices of global governance by drawing attention to their vulnerability and smallness. ${ }^{29}$ That is, rather than attempting to promote legitimacy via conformity, we argue that SIDS and SVEs have increasingly sought to demonstrate their vulnerability in a hierarchical world order in which large is stronger than small. Therefore, rather than a static

\footnotetext{
${ }^{25}$ Robert O. Keohane, 'Lilliputians' dilemmas: small states in international politics', International Organization, 23:2 (1969), p. 297; cf David Vital, The inequality of states: a study of the small power in international relations, (Oxford: Clarendon Press, 1967) ${ }^{26}$ Kronsell (2002); Ingebritsen (2002); Browning (2006); Deitelhoff and Wallbott (2012); Sarita Jackson, 'Small states and compliance bargaining in the WTO: an analysis of the Antigua-US Gambling Services Case', Cambridge Review of International Affairs, 25:3 (2012), pp. 367-85.; and Panke (2010), (2012a)

${ }^{27}$ For a review see Bishop (2012)

${ }^{28}$ Sharman (2015)

${ }^{29} \mathrm{Cf}$ David A. Rezvani, Surpassing the sovereign state: the wealth, self-rule, and security advantages of partially independent territories, (Oxford: Oxford University Press, 2014) on partially independent territories
} 
category, we treat the competent performance of vulnerability as a dynamic strategy that brings benefits, increases resilience and, in extreme cases, ensures survival.

By drawing attention to the way SIDS and SVEs have used their vulnerability to carve out a space for themselves in the multilateral world, we add to the existing literature on multilateral cooperation in IOs that emphasises the diverse power and influence of multiple actors, ${ }^{30}$ and support the emerging thesis that small states, individually or collectively, have already succeeded in placing their concerns on 10 agendas and 'generated international interest in their conditions', ${ }^{31}$ especially on climate change. ${ }^{32}$ Rather than being dependent on large states, we show that active and creative small states have used the label and the metaphor of smallness to realise specific goals. ${ }^{33}$ Our argument thus turns on the claim that SIDS and SVEs were not given the label or a place in IOs, they fought for them by drawing attention to their unique condition.

\section{Norm Entrepreneurship and Diffusion 'From Below'}

\footnotetext{
${ }^{30}$ E.g. Michael Barnett and Martha Finnemore, Rules for the world: International organizations in global politics, (Ithaca: Cornell University Press, 2004); Darren G. Hawkins et al., Delegation and Agency in International Organisations, (Cambridge: Cambridge University Press, 2006); and Deborah D. Avant, Martha Finnemore, and Susan K. Sell (eds.) Who governs the globe? Vol.114, (Cambridge: Cambridge University Press, 2010). ${ }^{31}$ Godfrey Baldacchino, 'Thucydides or Kissinger? A critical review of smaller state diplomacy,' The diplomacies of small states, in Andrew Cooper and Timothy Shaw (eds.) The diplomacies of small states: Between vulnerability and resilience, (Basingstoke: Palgrave Macmillan, 2009), pp. 21-40; cf Andrew Cooper and Timothy Shaw (eds.) The diplomacies of small states: Between vulnerability and resilience, (Basingstoke: Palgrave Macmillan, 2009); Kevin Jaschik, 'Small states and international politics: Climate change, the Maldives and Tuvalu', International politics, 51:2 (2014), pp.272-93; Tom Long, 'Small states, great power? Gaining influence through intrinsic, derivative, and collective power,' International Studies Review, 19:2 (2016), pp. 185-205.

32 e.g. Betzold, Carola, Paula Castro, and Florian Weiler, 'AOSIS in the UNFCCC negotiations: from unity to fragmentation?', Climate policy, 12:5 (2012), pp. 591-613; Pamela S. Chasek, 'Margins of power: coalition building and coalition maintenance of the South Pacific Island States and the Alliance of Small Island States,' Review of European, Comparative \& International Environmental Law, 14:2 (2005), pp. 125-137; and Inés de Agueda Corneloup and Arthur PJ Mol, 'Small island developing states and international climate change negotiations: The power of moral "leadership"' International Environmental Agreements: Politics, Law and Economics, 14:3 (2014), pp. 281-97.

${ }^{33}$ Cf Jourde (2007); Lee (2013) and Laker (2014) on African States.
} 
In addition to the literature on IOs, our argument that a dry and essentially static concept like vulnerability has been used by a group of structurally weak states to advance their interests in multilateral forums is significant because it contributes to theoretical debates about the relationship between norms and hierarchies. Specifically, we build on Towns's work on norm diffusion 'from below' ${ }^{34}$ Towns's intervention critiques the existing norms literature for assuming that diffusion always spreads from the core to the periphery, making large states, IOs and other transnational advocacy coalitions the primary norm diffusers. In Towns's account, which was employed to explain the rise of policies that sought to incorporate women into the state, diffusion was more dynamic. Indeed, she argues that countries on the periphery, who have a low rank in the hierarchical order, can increase their standing by initiating and adhering to norms.

Towns's conceptualisation rests on the following definitions and assumptions which we adopt in this study. First, that the international is social, constituted by inter-subjective knowledge, meaningful practices and social relations. Second, that identity is relational and creates differentiation between states by rendering them 'distinctly recognisable'. Identities are not fixed; they change and this change is important for how we explain why, for example, some states would come to see themselves as a distinctly recognizable group called SIDS or SVEs. Third, identity and differentiation mean Towns views norm diffusion as more than a process by which states become increasingly similar; norms simultaneously homogenize and stratify. Fourth, norms assign value and determine what constitutes valid behaviour for specific sorts of actors. Norms thus embody and create hierarchies of states. So, finally, to study norms is to study hierarchies and the inequalities they imply.

While our account of how norm diffusion 'from below' occurs owes a substantial debt to Towns, we also depart from her explanation in two important ways. First, like most norm scholars, Towns tacitly assumes that states take up norms to increase their rank in the global hierarchy. The development hierarchy, constituted by a host of economic indices, is slightly different to the state policies described by Towns in that while, as per convention,

${ }^{34}$ Towns (2010), (2012). 
rank increases as states become more 'developed', benefits in the form of trade concessions, concessional finance, and development assistance flow in the opposite direction to those who can demonstrate that they are poor and vulnerable. As a result, many SIDS and SVEs see little benefit in 'graduation' from a lowly rank as it will result in a 'middle income trap' in which they are unable to further develop once trade concessions, concessional finance and development assistance are removed. In these circumstances, many SIDS and SVEs see their interests as best served by either delaying graduation (as was recently the case in Antigua and Barbuda after Hurricane Irma), or, as outlined here, by prosecuting a case for differentiated development. In doing so they aim to alter the system by which graduation occurs.

The idea that states would seek to dispense with or reinvent a hierarchical order 'from below' is consistent with Towns. The crucial point, and one on which our argument turns, is that 'development' is only one hierarchy in which SIDS and SVEs are situated; the perception of state size is related to economic size but in the international sphere it is also a distinct hierarchy. Thus, while it initially implies a reduced rank, the constitutive norm of differentiated development, once accepted, would eventually result in SIDS increasing their rank on development indices (or at least that is the aim). Nevertheless, maintaining the benefits (i.e. trade concessions at the WTO) that could enable this to occur would be contingent on continued acceptance of their vulnerability and thus a lowly rank in the related hierarchy, defined by size, in which large is stronger than small. Consequently, rather than seeking to increase their standing via conformity, SIDS and SVEs are attempting to stress their weakness in return for benefits that will assist their development.

The important caveat here is that while SIDS and SVEs in the Caribbean, Pacific and Indian Ocean regions have pursued this strategy, European small states, which tend to be richer, have historically preferred the more conventional route of seeking to act as if they were a large state to protect their 'status' ${ }^{35}$ Interestingly, however, as the WHO example discussed below illustrates, the norm of differentiated development is spreading and so even countries that have not previously identified as SIDS (i.e. Malta or Cyprus) are nevertheless

${ }^{35}$ de Carvalho and Neuman (2015). 
adopting similar discursive strategies on issues like health, for example. Whether this will prove beneficial remains to be seen. Similarly, while we are at pains to show that the SIDS and SVEs label has already generated assistance, it is important to note that one of the main benefits they hope to achieve, but as yet remains unrealised, is compensation for the adverse consequences of climate change, also referred to as 'loss and damage' (Vanuatu's Foreign Minister declared at a Nov 2018 meeting of the Climate Vulnerable Forum that his country is exploring whether it can take legal action against fossil fuel companies and countries, for example). ${ }^{36}$ Again, whether they will be successful in this pursuit is an open question. However, SIDS and SVEs could not prosecute the case without the label and associated identity which is synonymous with acute vulnerability. Indeed, it may be that SIDS and SVEs are unsuccessful in pursing 'loss and damage' compensation but the constitutive norm 'differentiated development' remains.

The second point of departure from Towns is our emphasis on agency. We see SIDS and SVEs as 'norm entrepreneurs' and their deliberate efforts consequential in much the same way as mainstream agentic norms scholars. This is consistent with the interpretive approach we employ (discussed further below). Towns self-identifies as being uneasily situated between this approach and that of critical constructivists and its dynamic cultural structuralism. ${ }^{37}$ While the differences between our respective positions should not be overstated, we posit that a consciously agentic perspective provides scope for us to view states as pursuing their perceived interests by moving up and down social hierarchies. To be clear, we are not saying SIDS and SVEs are autonomous. We acknowledge that the case we elucidate is contingent on an advantageous international regime of norms, ${ }^{38}$ including the sovereign equality of states and the right to development, and has been given impetus by the disproportionate impact of climate change on many SIDS and SVEs, which has proven to be a difficult moral claim for larger states to deny. But, at the same time the creation of the SIDS and SVEs category was not inevitable nor the process seamless; existing inter-

\footnotetext{
${ }^{36}$ Lisa Cox (2018), 'Vanuatu says it may sue fossil fuel companies and other countries over climate change', The Guardian, available at \{https://www,theguardian,com/world/2018/nov/22/vanuatu-says-it-may-sue-fossil-fuelcompanies-and-other-countries-over-climate-change\} 22 November 2018 37 Towns (2010), p. 53

${ }^{38}$ Alberto Alesina and Enrico Spolaore, The size of nations, (Cambridge: MIT Press, 2005)
} 
subjective norms may be a necessary condition for change but they are not sufficient. This case cannot be explained without also accounting for the entrepreneurship of SIDS and SVES in the face of opposition from larger and more powerful actors.

Our emphasis on agency and our recognition that change does not occur automatically highlights the importance of persuasion, which is a mainstay of the norms literature. We use the word competent to denote the importance of persuasion. The importance of 'competence' highlights that the case must be embedded in existing processes in order to perceived by others as more than 'whinging' or complaining. The creation of the label would not have occurred if SIDS and SVEs had not couched their claim to vulnerability as an extension of existing liberal moral principles-the right to development and the sovereign equality of states. But, they also had to choose the right forums and approach within existing rules, and this meant active participation in the processes and practices of IOs. We posit that if their performance of vulnerability had invoked different existing norms, been less coordinated, or was pursued outside multilateral forums, then the label would either not exist or have an alternate meaning. The competent performance of vulnerability thus occurs in three ways:

1. Rhetorical action ${ }^{39}$ of the type identified by scholars working on the agency of African states in the international system, ${ }^{40}$ that invokes existing norms in multilateral forums to highlight the unique economic and environmental circumstances of SIDS and SVEs and posits that they cannot be overcome by conventional development strategies;

2. Collaboration or coalition building between SIDS and SVEs to take advantage of the principle of sovereign equality and the preference for consensus within IOs. ${ }^{41}$ Both allow SIDS and SVEs to act as veto players on key decisions and leadership selections.

\footnotetext{
${ }^{39}$ Schimmelfennig (2001); cf Christopher S. Browning, 'Small, smart and salient? Rethinking identity in the small states literature', Cambridge Review of International Affairs, 19:4 (2006), pp. 669-84

${ }^{40}$ E.g. Jourde (2007); Lee (2013); Laker (2014)

${ }^{41}$ Deitelhoff and Wallbott (2012); Panke (2012a)
} 
By threatening vetoes, SIDS and SVEs have been able to demonstrate that they can act as a grouping that justifies its own label in IOs; and

3. Active participation ${ }^{42}$ in the processes and everyday practices of 10 s, including proposing initiatives or motions; holding leadership positions, taking up positions on boards and other decision-making bodies; co-ordinating positions; drafting text; holding press conferences and issuing press releases; briefing ministerial groups, delegations and taskforces; and attending workshops, meetings and conferences. The reason participation in the processes and practices of IOs is a necessary condition in our explanation is that the presence of SIDS and SVEs in IO decisionmaking cannot be assumed due to well-known capacity deficits, ${ }^{43}$ where large states can have missions and delegations for most if not all IOs, SIDS and SVEs are often defined by their absence. A focus on the weakest and most peripheral members reveals, therefore, that norm diffusion is always contingent on presence.

Having made this claim, the important caveat we must state from the outset is that we are not saying that the other mechanisms-e.g. learning, emulation, and competition $-{ }^{44}$ for norm diffusion are not relevant for this case. Clearly individual SIDS and SVEs have learned from their success in the UN and attempted to replicate it across other IOs, even if with mixed results. Our account thus supports recent work on norm diffusion across IOs that highlights the importance of interconnectivity between formal and informal networks of actors. ${ }^{45}$ Likewise, other IOs have sought to emulate the UN by pursuing a 'development agenda'. Further, competition between IOs seeking to remain relevant to a dwindling pool of 'developing' client states could explain their increased interest in SIDS. ${ }^{46}$ Indeed, some

\footnotetext{
42 Panke (2012a)

${ }^{43}$ Cf Wallis (2010); Corbett, Jack, and John Connell (2015)

${ }^{44}$ David Marsh and Jason C. Sharman, 'Policy diffusion and policy transfer,' Policy studies, 30:3 (2009), pp. 269-88; Maggetti and Gilardi (2016)

${ }^{45}$ Sommerer, Thomas, and Jonas Tallberg. "Diffusion across International Organizations: Connectivity and Convergence." International Organization, Ahead-of-print DOI: https://doi.org/10.1017/S0020818318000450 (2019), pp. 1-35 ${ }^{46}$ Corbett, Jack, Xu Yi-Chong, and Patrick Weller. "Small states and the 'throughput'legitimacy of international organizations." Cambridge Review of International Affairs. Ahead-of-print DOI: https://doi.org/10.1080/09557571.2018.1493048 (2018): 1-20
} 
large states have sought to further their own agenda in IOs by supporting smaller ones. So, we are not seeking to refute the claim that these other explanations matter. Rather, each has important limitations for explaining this case.

An account that privileged the explanatory power of learning would emphasise the contribution of SIDS and SVEs to the operation of IOs. The rise of SIDS and SVEs has generally been accepted even though many within IOs see them as 'irritants', responsible for gridlocks and delays, ${ }^{47}$ and that 'differentiated development' undermines the status of larger developing states (i.e. the BRICS). Likewise, while emulation offers some insights into the claims to exceptionalism employed by groupings of SIDS and SVEs, it tells us very little about the variation and evolution of the definition of small state between 10 s. ${ }^{48}$ It also assumes that the strong, rather than the weak, are the driver of norm emergence and diffusion. Finally, competition between IOs can perhaps explain why they are interested in SIDS and SVEs, but it has less empirical purchase when seeking to account for why some states are interested in being classified as small in some IOs, but not others.

\section{Approach, Case Selection and Data}

Our methodological approach draws on the extensive interpretive political science literature. ${ }^{49}$ Interpretivists see intersubjectively held traditions (or norms) as co-constituted by agents in everyday practice: actors are socialised into traditions but also alter them as they interpret and enact them. Agents are thus 'situated'-actions and practices do not take place on a tabula rasa. Our claim, that the competent performance of vulnerability in institutional settings can lead to norm emergence and diffusion, thus follows a well-worn

\footnotetext{
47 Vaughan A. Lewis, 'Studying Small States over the 20th into the 21st Centuries,' in Andrew Cooper and Timothy Shaw (eds.) The diplomacies of small states: Between vulnerability and resilience, (Basingstoke: Palgrave Macmillan, 2009), p. vii.

${ }^{48}$ Antje Wiener, The Invisible Constitution of Politics, (Cambridge: Cambridge University Press, 2008), p. 63

${ }^{49}$ Peregine Schwartz-Shea and Dvora Yanow, Interpretive research design: Concepts and processes, (Abingdon: Routledge, 2013); Mark Bevir, Oliver Daddow, lan and Hall, Interpreting Global Security, (London: Routledge, 2013); Mark Bevir and Rod AW Rhodes (eds.) Routledge handbook of interpretive political science, (London: Routledge, 2015).
} 
interpretive logic: that the meanings and beliefs of situated agents, embedded within existing traditions (norms), causes them to act in certain ways. When traditions conflict they present actors with a dilemma. In this case, the key dilemma is the impending impact of climate change on SIDS and SVEs. As actors resolve these dilemmas in practice they alter existing norms. This is an explicitly causal claim based on the principle of 'meaning holism' rather than isolating atomised 'mechanisms'. ${ }^{50}$

As 'unlike units', SIDS and SVEs can tell us much about the international system and its potentially hierarchical nature ${ }^{51}$ because they are a proxy for active membership or the 'strength of the weak' in IOs. ${ }^{52}$ Dismissing SIDS and SVEs flouts the general social science approach to selecting cases-representativeness and variation $-{ }^{53}$ by focusing on great powers. ${ }^{54}$ Here we reverse that trend. SIDS and SVEs are thus 'least likely' ${ }^{55}$ cases of norm entrepreneurship as they are typically seen as weak states not only because they lack capacity and thereby power, ${ }^{56}$ but also because they 'exhibit a low level of participation in world affairs'. ${ }^{57}$ When they do participate, SIDS and SVEs are often conceptualised as being

${ }^{50}$ Mark Bevir, The Logic of the History of Ideas, (Cambridge: Cambridge University Press, 1999)

51 John M. Hobson and Jason C, Sharman, 'The enduring place of hierarchy in world politics: Tracing the social logics of hierarchy and political change', European Journal of International Relations, 11:1 (2005), pp. 63-98

52 Peter J. Katzenstein, Small states in world markets: Industrial policy in Europe, (Ithaca: Cornell University Press, 1985)

53 John Gerring, 'Is there a (viable) crucial-case method?' Comparative Political Studies, 40:3 (2007), pp. 231-253; Veenendaal, Wouter P., and Jack Corbett. "Why small states offer important answers to large questions." Comparative Political Studies 48.4 (2015): 527-549 ${ }^{54}$ Sharman (2017)

55 Eckstein, Harry, 1975, 'Case Studies and Theory in Political Science,' in Fred Greenstein and Nelson Polsby (eds.), Handbook of Political Science, Vol, (Reading, MA: Addison-Wesley, 1975), pp. 794-137

${ }^{56}$ Whether economic or human capital and population size, see Stephen D. Krasner, Structural conflict: The third world against global liberalism, (Berkley: University of California Press, 1985); Barbara Kotschwar, Patrick Low, and Miguel Rodriguez Mendoza, Trade Rules in the Making: Challenges in regional and Multilateral Negotiations, Organization of American States, (Washington DC: Brookings Institution Press, 1999); Diana Tussie, and Miguel Lengyel, 'Developing countries: turning participation into influence,' Development, Trade and the WTO: A Handbook, (Washington, DC: World Bank, 2002)

57 Jeanne A.K. Hey (ed.), Small states in world politics: Explaining foreign policy behaviour, (Boulder: Lynne Rienner Publishers, 2003) 
pawns of the powerful ${ }^{58}$ with whom they seek 'shelter' 59 and other benefits derived from conformity to institutionalised global norms. ${ }^{60}$ We show that these conclusions only tell part of the story, and, on that basis, we posit that if we can demonstrate how their competent performance of vulnerability matters then our agentic account has considerable explanatory power.

Much of the diffusion literature is based on large $\mathrm{N}$ quantitative work. ${ }^{61}$ One distinguishing feature of an interpretive approach is that it champions qualitative, fine grained, and historically situated analysis. Empirically we focus on the interaction between the established operating traditions and procedures of IOs, which were agreed upon more than a half century ago and still have binding force on member states, and the practices that shape both routines and expectations. Our account is 'experience near' 62 and thus adopts an 'ethnographic' sensibility. ${ }^{63}$ We primarily rely on 89 interviews with past and present diplomats and international civil servants. The interview sample was snowballed-we started with present-day diplomats who then put us in touch with their predecessors. As above, we made no effort to define 'small state' but rather talked to diplomats from states who acted under that label in IOs, specifically in the UN system, Commonwealth, WTO, World Bank, WIPO, and the WHO. The choice of IOs emerged iteratively as we asked small state diplomats which IOs they engaged in, and why. We then sought out officials in these

\footnotetext{
${ }^{58}$ Wouter P. Veenendaal, 'Analyzing the Foreign Policy of Microstates: The Relevance of the International Patron-Client Model,' Foreign Policy Analysis 13:3 (2017), pp. 561-77

59 Baldur Thorhallsson, 'Domestic buffer versus external shelter: viability of small states in the new globalised economy,' European Political Science Review 10:3 (2011), pp. 324-36 60 Jason C. Sharman, 'War, selection, and micro-states: Economic and sociological perspectives on the international system,' European Journal of International Relations 21:1 (2015), pp. 194-214

${ }^{61}$ Marsh and Sharman (2009); Maggetti and Gilardi (2016)

${ }^{62}$ Patrick Thaddeus Jackson, and Daniel H. Nexon, 'International theory in a postparadigmatic era: From substantive wagers to scientific ontologies,' European Journal of International Relations, 19:3 (2013), pp. 543-65

63 John Boswell et al. 'State of the Field: What Can Political Ethnography Tell Us About AntiPolitics and Democratic Disaffection?', European Journal of Political Research (2017), Aheadof-print DOI: 10.1111/1475-6765.12270
} 
IOs who work on small state issues to gain their perspective. ${ }^{64}$ When selecting small states our aim was to gain a breadth of perspectives-rich and poor, different regions, different levels of engagement in IOs, etc. - so as to ensure our analysis was holistic. ${ }^{65}$ We also spoke to diplomats from larger states who support small states in pursuing their issues. ${ }^{66}$ Given the emphasis on SIDS and SVEs in this article, we primarily rely on that interview data here (68 interviews were conducted with diplomats from SIDS, SVEs or their IO counterparts).

Our interview questions focused on the everyday practice of small state diplomacy-we wanted to know when and how SIDS and SVEs participate in IOs; in which IOs and on what issues; and what the challenges and opportunities of participation are. We then augmented their account with documentary records (e.g. major reports on SIDS by IOs, reports from UNSIDS conferences, regular WTO reports on the SVE work program, etc. We use conventional citations for these sources below but this represents only a fraction of the material consulted); we traced how actors interpreted practises and processes across IOs and across time. ${ }^{67}$ In some instances, we were allowed to observe meetings and participate in conferences. When interviewees gave us instances of when and how their participation had mattered in IOs, we followed this up by accessing formal agenda, minutes and voting records. We then went back to interviewees to confirm the accuracy of the written account. We employ key quotes selectively to demonstrate key themes - they are thus illustrative of the broader dataset and we could have included many more to buttress each point. The result is an historically-orientated description of the practice of small state participation across IOs over more than two decades.

${ }^{64}$ The officials came from: AOSIS, ComSec, FAO, IMF, IMO, OECS, PIDF, PIFS, UNDP, WB, WHO, WTO, and WIPO. In many cases we interviewed far more than one official from each 10.

65 The small states were: Antigua and Barbuda, Bahamas, Barbados, Brunei, Botswana, Cape Verde, Costa Rica, Cyprus, Estonia, El Salvador, FSM, Fiji, Guatemala, Guyana, Haiti, Iceland, Jamaica, Kiribati, Maldives, Malta, Malawi, Mauritius, Nauru, Palau Samoa, Seychelles, Solomon Islands, St Kitts and Nevis, St Vincent and the Grenadines, Tuvalu, Tanzania, and Vanuatu. In many cases we interviewed more than one diplomat from each small state.

${ }^{66}$ E.g. United Kingdom, Australia, Switzerland , Sweden, Norway, Canada and New Zealand 67 Vincent Pouliot, 'Practice tracing', in Andrew Bennett, and Jeffrey T. Checkel (eds.) Process Tracing: From Analytic Metaphor to Best Practices, (Cambridge: Cambridge University Press, 2014), pp. 237-259, 


\section{Small States and the Multilateral World: The Rise of a Label}

The countries that are typically considered SIDS and SVEs today were engaged in international affairs long before they assumed a distinct label. ${ }^{68}$ On achieving independence in the decades after the Second World War they joined the UN. They were members of the African, Caribbean and Pacific Group (ACP), for example, which has been in existence since 1975. Outside the UN, the most prominent champion of the SIDS agenda has been The Commonwealth. ${ }^{69}$ SIDS make up two thirds of the Commonwealth's membership; the Commonwealth therefore has a vested interest in these states and their issues. The Commonwealth has also provided an office for SIDS seeking to represent themselves in New York since the 1980s. They held the first Ministerial Group on Small States (MGSS) in 1993. The MGSS met 6 times between 1993 and 2006. It has been replaced by an Open-ended Ministerial Group on Small States. The Commonwealth also began holding a Global Biennial Conference on Small States in 2010. The Commonwealth has altered its definition of small states during this period. ${ }^{70}$ As per Table 1, the 1997 definition includes states with populations over 1 million who share similar characteristics and regional links with small states (i.e. Papua New Guinea and Jamaica).

Individual IOs have also offered opportunities for small states to cooperate. The World Bank and WTO provide examples where the institutional rules of IOs can be strategically influenced by active SIDS and SVEs. These rules may not always favour SIDS and SVEs as much as they do in the UN system but the ability to exercise vetoes in systems based on consensus and use numbers in leadership selections are still significant. Indeed, we argue that the institutional rules and practices can also explain why a label has not emerged in all IOs.

${ }^{68}$ Vital (1967); David Vital, The survival of small states: studies in small power/great power conflict, (Oxford: Oxford University Press, 1971)

${ }^{69}$ Commonwealth Consultative Group, Vulnerability: Small States in the Global Society, (London: Commonwealth Secretariat, 1985); Commonwealth Advisory Group, A Future for Small States: Overcoming Vulnerability, (London: Commonwealth Secretariat, 1997)

70 Sutton (2011) 
The first caveat therefore is that we are not claiming to tell the story of each small state, or indeed the multitude of ways the countries we now refer to as SIDS and SVEs engage in diplomatic affairs. Rather, we seek to tell the story of the SIDS and SVEs label in IOs. By IOs we primarily mean institutions of global governance, rather than regional institutions like the EU. ${ }^{71}$

Second, while some actors from SIDS and SVEs have had a vision for collective action, these states have no collective grand strategy for doing so across multiple IOs. Reflecting this adhoc emergence, each IO has a different definition of what a small state is and some countries are considered small states on certain issues but not others. Indeed, as outlined below, discussion among SIDS and SVEs themselves about who should be able to assume the label is central to debates about differentiated development in IOs.

\section{Rhetorical action}

[For] the Maldives, a mean sea level rise of 2 metres would suffice to virtually submerge the entire country of 1,190 small islands ... That would be the death of a nation. ${ }^{72}$

It is impossible to determine a precise date for when the label small state came into common usage in IOs as it has emerged iteratively in everyday diplomacy. 'Microstate' is a term that has been used at the UN since at least the 1960s and UNCTAD set in motion studies on island developing states in the 1970 s. ${ }^{73}$ The general consensus is that group consciousness was heightened by international recognition of climate change in the late 1980s and early 1990s. As the above quote illustrates, the Maldives, a low-lying atoll nation in the Indian Ocean, claims to be the first country to talk about the impact of climate change

\footnotetext{
${ }^{71}$ See Baldur Thorhallsson and Anders Wivel, 'Small states in the European Union: what do we know and what would we like to know?', Cambridge Review of International Affairs, 19:4 (2006), pp. 651-668; Diana Panke, Small states in the European Union: coping with structural disadvantages, (Farnham: Ashgate Publishing, 2010)

72 President of the Republic of the Maldives, Maumoon Abdul Gayoom, Address to the 42nd Session of the UN General Assembly on the Issues of Environment and Development, 19. October 1987. New York (1987)

${ }^{73}$ Sutton (2011), p. 143
} 
on small states at the UN. In 1989 the first Small States Conference on Sea Level Rise was held in Male, Maldives. It was funded jointly by the Commonwealth and Australia. The vulnerability of islands and low-lying islands in particular to sea level rise was later recognized by the 44th session of the UN General Assembly (resolution 44/206) in 1989, which expressed concern that:

sea-level rise resulting from global climate change could lead, inter alia, to abnormally high tides, which could intensify flooding and the erosion of coastal areas and damage infrastructure on islands and in low-lying coastal areas,

And recommended:

that the vulnerability of affected countries and their marine ecosystems to sea-level rise be considered during discussions of a draft framework convention on climate as well as within the framework of the United Nations conference on environment and development to be held in 1992 and during the preparatory process for the conference

The Commonwealth had a different definition. In July 1998 a MGSS delegation met with the President of the World Bank to discuss the SIDS Agenda. This led to the creation of the Commonwealth / World Bank Joint Task Force on Small States which produced an Interim Report on "Small States: Meeting Challenges in the Global Economy" that was considered and adopted at the global conference on the development agenda for SIDS, in London, UK, in 2000. This report described small state vulnerability as:

The above factors-remoteness and isolation, volatile economic growth, investor perceptions, high poverty and limited institutional capacity-suggest intuitively that small states would be more vulnerable than their larger developing country counterparts. Vulnerability means exposure to exogenous shocks over which the 
affected country has little or no control, and relatively low resilience to withstand and recover from these shocks. ${ }^{74}$

A result of this report the Commonwealth definition of a small state became the World Bank definition. The Bank's Small States Forum has been held every year since 2000 during the Annual Meetings, bringing together Finance Ministers and Central Bank Governors from 50 small states.

In other IOs, such as WHO, WIPO and the UNHRC, small states claim that the factors that make small state economies vulnerable apply equally to health. For instance, the main drivers of health outcomes-e.g. food supply and quality-are global and small states economies are, more vulnerable to fluctuations and quality of supply. Likewise, economies of scale-the cost of equipment and pharmaceuticals, and the availability of skilled labourlimit medical treatment in small states. But, despite their interests and the fact that individual small states have found the WHO to be receptive to these arguments, there is no equivalent to the SIDS grouping in the WHO.

\section{Collaboration}

The 1989 meeting in Maldives and the impending FCCC negotiations inspired the formation of AOSIS in 1990, which at the time comprised 24 island states under the leadership of Maldives, Vanuatu and Trinidad and Tobago. Since then, membership has grown to 39 members plus 5 observers, all of whom coordinate positions at the UN. ${ }^{75}$ Member states of AOSIS work together primarily through New York diplomatic missions, with major policy decisions taken at ambassadorial-level plenary sessions. ${ }^{76}$ AOSIS has no formal charter or secretariat but receives considerable pro-bono technical assistance. ${ }^{77}$

\footnotetext{
${ }^{74}$ Commonwealth Secretariat and World Bank, Small states : meeting challenges in the global economy (English), (Washington DC: World Bank, 2000), p. 19

${ }^{75}$ Betzold et al. (2012)

${ }^{76}$ Chasek (2005)

${ }^{77}$ Carola Betzold, "Borrowing" power to influence international negotiations: AOSIS in the climate change regime, 1990-1997' Politics 30:3 (2010), pp. 131-48
} 
The success of AOSIS in the deliberations on climate change in the early 1990s is well documented. ${ }^{78}$ In the negotiating committee set up by United Nations General Assembly (UNGA) to develop a climate change convention, the chair of AOSIS, Suriname-born Robert F. Van Lierop, then Permanent Representative of Vanuatu to the United Nations, set three goals $^{79}$ :

1. to devise a common negotiating position at the intergovernmental negotiating committee (INC) for a frame- work convention on climate change;

2. to focus world attention on the plight of small island countries in the face of the threat of global warming; and

3. to consider strategies to cope with its damaging effects and to ensure that AOSIS' interests were properly addressed by an effective Convention.

To achieve these goals, AOSIS had 12 key objectives; in the majority of cases (10 of 12) they were successful in getting their preferred wording in the draft text. For example, their first objective was that the preamble should expressly recognize the problems and unique vulnerability of small island countries. This position is reflected in the text agreed and adopted at the Fifth Session of the Intergovernmental Negotiating Committee for a Framework Convention on Climate Change on 9 May 1992.

Part of the reason for the success of AOSIS was the considerable goodwill among the international community towards small and vulnerable countries. Van Lierop and John Ashe, ${ }^{80}$ representative for Antigua and Barbuda, argue that the weight of the group and its numbers as a negotiating bloc were also important. We might add that AOSIS enjoyed a first-mover advantage vis-à-vis other groups ${ }^{81}$ and that the process of UNFCCC deliberations-six intensive, two-week long negotiating sessions over 14 months leading up

\footnotetext{
78 John W. Ashe, Robert Van Lierop, and Anilla Cherian, 'The role of the alliance of small island states (AOSIS) in the negotiation of the United Nations framework convention on climate change (UNFCCC)' Natural Resources Forum, 23:3 (1999), pp. 209-20

79 Ashe et al. (1999), p. 210

${ }^{80}$ Ashe et al. (1999), p. 219

${ }^{81}$ Betzold (2010)
} 
to the 1992 Rio Conference-advantaged the skilled diplomats who led AOSIS during this period, rather than unwieldy bureaucratic teams.

AOSIS success in the UNFCCC process illustrated the potential of the group. This was confirmed at the United Nations Conference on Environment and Development in Rio de Janeiro, 1992 where they again succeeded in inserting their position in the formal text. ${ }^{82}$ Agenda 21 makes numerous references to the unique challenges of small islands, designating them a 'special case' $(17.123)$ by virtue of their fragility and vulnerability to environmental hazards. It further noted that SIDS would require cooperation from the international community to meet these challenges (17.126). In addition to a work program, \$130 million funding commitment, and a decision to hold the first ever UN conference on small states, Agenda 21 also urged that other IOs recognize the unique circumstances of SIDS.

Small states' representation at the World Bank and the IMF differs from other IOs. There are a limited number of Executive Directors (ED) in each IO; some represent individual countries, but the majority represent groupings of countries. Most of the Anglophone Caribbean countries are in a group where Canada provides the ED. The Pacific countries are in a grouping where the ED rotates between Australia, New Zealand and South Korea. The members of the group take turns in providing representatives to serve in the EDs' office. The EDs insist they represent all the countries in their group. 'I am an Executive Director, not an Ambassador,' one insisted. When Prime Minister of Barbados and leader of the Joint Task Force, Owen Arthur, wanted to present the report at the Bank his appearance was arranged by the (Canadian-led) ED's office as Barbados is a member of the group. Ultimately the World Bank's Development Committee broadly accepted the recommendations of the report but did not endorse a new category that would see small states treated like LDCs. ${ }^{83}$ As we will elaborate further below, a key reason is that the principle of sovereign equality provides SIDS greater leverage at the UN when compared to the weighted voting of the Bank, and that may have altered the outcomes.

82 UNCED, Agenda 21: Programme of action for sustainable development. Rio Declaration on Environment and Development, Rio de Janeiro, 1992

${ }^{83}$ Sutton (2011), p. 147 
The 1998 joint Commonwealth-World Bank report noted earlier also had an influence at the WTO which, at the time, was in the midst of deliberating about whether to commence a new round of trade negotiations. When the EU demanded that one set of issues be included on the agenda, and then India and others sought a second tranche, SVEs wanted their voice heard. As a WTO official ${ }^{84}$ explained:

Barbados, leading the SIDS from the UN, said, "we want a work program on small economies"... Mike Moore [then Director General of the WTO]... was basically the one who was Mr Small States. So, he played to Barbados and said "we'll get you your work program".

The need for consensus assisted their case. They had to be brought on board for the Round to be launched.

Here, again, the existing rules of IOs mattered but, in this case, the potential to act as veto players favoured SVEs, with the 2001 Doha Ministerial Declaration duly establishing a work program on Small and Vulnerable Economies (SVEs). In keeping with the focus of the WTO, the term 'small, vulnerable economies'

applies to Members with economies that, in the period 1999 to 2004, had an average share of (a) world merchandise trade of no more than 0.16 per cent or less, and (b) world trade in non-agricultural products of no more than 0.1 per cent and (c) world trade in agricultural products of no more than 0.4 per cent. ${ }^{85}$

Even though the WTO category encompasses many SVEs that are not islands, including a number of Latin American countries, the lessons drawn from experiences at the UN in New York were nevertheless applied to the WTO in Geneva by representatives of the SIDS.

\footnotetext{
${ }^{84}$ Author interview, March 2017

${ }^{85} \mathrm{TN} / \mathrm{AG} / \mathrm{W} / 4 /$ Rev.4/ paragraph. 157.
} 
By contrast in the WHO decisions about levels and types of assistance to the health departments of SIDS are primarily taken in the semi-independent regional offices, rather than through diplomatic channels in New York and Geneva. The interests of SIDS can sometimes be lost within larger blocks-e.g. Western Pacific Region. Further, it is difficult for a small state group to be coordinated in Geneva as most small state diplomatic posts do not have staff dedicated to covering the WHO. One exception is the WHO European Region's small countries initiative. The eight members of the initiative are: Andorra, Cyprus, Iceland, Luxembourg, Malta, Monaco, Montenegro, and San Marino. All have populations of 1 million or less. Echoing our emphasis on process, the initiative was founded in 2013 at an informal meeting during the 63rd session of the WHO Regional Committee for Europe. A high-level meeting was subsequently organized in July 2014, by San Marino. Again, the key to its success has been the ability to combine the rhetoric of vulnerability with procedural mechanisms:

It was I think a little bit of politics. The regional director was up for her renewal, eight small states is eight votes and she committed to do something specific for the small states. San Marino put up the initial funding. ${ }^{86}$

Attempts to create an African SIDS group are also being discussed. The key caveat here is, of course, that these states are not SIDS or SVEs. We take this development in WHO as evidence that the discourse of vulnerability has become so pervasive that even wealthier small states have begun to perform it.

\section{Active Participation}

The creation of an identifiable UN grouping, separate but emerging from AOSIS, was not a given. As one Caribbean diplomat ${ }^{87}$ recalls:

\footnotetext{
${ }^{86}$ Interview with a former Chief Medical Officer from a European small state, November 2017.

${ }^{87}$ Author interview, August 2016.
} 
We were told then you're never going to get another category within the United Nations. "We're done with categories; there are too many of them already" [they said] ... "it won't happen, it won't happen". We fought for years and years and it did happen.

You just wear them down. In other words, if they say it's not going to be a category. Okay but this what we're doing, we want a plan of action - incrementally, it just sticks. You call yourselves something, you group yourselves ... Then it can't be reversed ...

Because obviously one on one you don't stand a chance. But it is the weight of numbers ... because the issues are so clear cut, the level of coordination and likemindedness becomes easier. I mean there isn't a whole range of differences or nuances [between small states] where it comes to climate change. Things like that can galvanise a constituency and then they hang together.

Within the UN system the SIDS label was created for the Global Conference on the Sustainable Development of Small Island Developing States in Barbados, 1994. This conference followed the success of Rio and helped consolidate the emerging group and its agenda by translating the principles embodied in Agenda 21 into specific policies contained in the Declaration of Barbados and the Programme of Action for Sustainable Development of Small Island Developing States.

The membership of SIDS was decided in the lead-up to the conference by a single UN official $^{88}$ who recalls:

I said let's make it 10 million and that was that ... [it's] the population of Cuba ... We wanted Cuba's political strength ... the energy that the Cubans would bring to bear ... [and] the fact that they were not easily intimidated ... They could [also] be a useful nuisance ... If western powers wanted to change something that small islands were

${ }^{88}$ Author interview, October 2016 
putting forward then you had Cuba as a scapegoat ... "Look at these crazy Cubans. What can we do with them?"

SIDS have held specific seats on the various UN bodies dedicated to tackling climate change, a role on the Executive Board of the Clean Development Mechanism, and the boards of the Adaptation Fund and the Green Climate Fund. ${ }^{89}$ The exceptional vulnerability of this grouping has been affirmed at two subsequent SIDS conferences: Mauritius in 2005 and Samoa in 2014. It has also been acknowledged at all of the major UN conferences and summits on economic, social and environmental issues since 1994. More recently, SIDS via AOSIS, played a crucial role in the negotiating period during CoP21 and the subsequent Paris Agreement. ${ }^{90}$ Consistent with more than two-decades of activism, they succeeded in highlighting their special circumstances as vulnerable countries and in doing so pushed for ambitious long-term temperature targets. They also succeeded in ensuring that loss and damage will be part of the ongoing global discussions about the impact of climate change. ${ }^{91}$

Part of their success has been the ability to define common positions, speak with one voice, build coalitions with other states, and in doing so ensure their positions are included in the final texts. ${ }^{92}$ Chief climate change negotiator for the Pacific Island state of Tuvalu, Ian Fry, ${ }^{93}$ reflects that:

In these [CoP] processes, the SIDS tried to use a variety of groupings, processes and tactics to elevate their interests. During 2015, the Republic of the Marshall Islands began convening meetings of ministers in the margins of the preparatory negotiations. The ministers were handpicked "like-minded" countries who were keen on setting a level of "high ambition" within the agreement. It included

\footnotetext{
89 Betzold et al. (2012)

${ }^{90}$ For discussion see Timothée Ourbak and Alexandre K, Magnan, 'The Paris Agreement and climate change negotiations: Small Islands, big players, A commentary,' Regional Environmental Change, 18 (2017): pp. 1-7

${ }^{91}$ Ian Fry, 'The Paris Agreement: An Insider's Perspective-The Role of Small Island Developing States,' Environmental Policy and Law, 46:2 (2016) 105, pp. 105-08

92 De Agueda et al. (2014), p. 281

${ }^{93}$ Fry (2016), p. 106
} 
countries from Latin America, the Pacific, Europe (including the European Commission) and Africa ... This group began as an informal exchange of views on how to drive a high-ambition agenda. Indeed, during the Paris Conference of Parties, it became known as the "High Ambition Group". It began to hold press conferences under this banner. Just prior to CoP-21, the US was invited to attend a meeting of the group and joined forces with them. This tended to add theatrical air and political muscle to the group. At one of the plenary sessions of the CoP, the group walked in together under rousing applause and cheers from various well-primed observers. It appeared more like a Presidential rally than a CoP.

As this comment illustrates, what began as informal meetings initiated by the smallest states in the world ended up drawing in one of the 'great powers' and had considerable influence on a key international agreement that may shape the future of the planet. Likewise, SIDS active participation was the key to the establishment of Sustainable Development Goals (SDGs) 13 (Climate Action) and 14 (Life Below Water), with the latter resulting in the inaugural United Nations Oceans Conference held in Malta in 2017. The key figure pushing this agenda, now the UN Secretary-General's Special Envoy for the Ocean, was Peter Thomson, formerly Fiji's Permanent Representative to the United Nations and President of the General Assembly in 2016-2017.

SIDS have not had it all their way since 1992. Indeed, after further success at Kyoto in $1997,{ }^{94}$ there were fears the SIDS agenda had stalled at the UN ${ }^{95}$ Retaining group cohesion has been a problem, especially as the size of AOSIS has expanded. ${ }^{96}$ These issues were apparent as early as Barbados and were prominent in Mauritius. ${ }^{97}$ As a result, SIDS subgroups, including the Pacific SIDS (PSIDS), the CARICOM Community, and the Coalition of

\footnotetext{
94 Nicolette Goulding, 'Marshalling a Pacific Response to Climate Change',), pp. 191-204; George Carter, 'Establishing a Pacific Voice in the Climate Change in Greg Fry and Sandra Tarte (eds.), The New Pacific Diplomacy, (Canberra: ANU Press, 2016, pp. 205-22

${ }^{95}$ Chasek 2005; Ian Fry, 'Small island developing states: becalmed in a sea of soft law', Review of European, Comparative \& International Environmental Law, 14:2 (2005), pp. 89-99

${ }^{96}$ Chasek (2005); Fry (2005), (2016); Betzold (2012)

${ }^{97}$ Chasek (2005)
} 
Coral Atoll Nations, have spun off to represent distinct interests. ${ }^{98}$ Reflecting this diversity, in the same year as the Rio conference Singapore established an informal grouping of small states in New York known as the Forum of Small States (FOSS). Today FOSS comprises 107 countries that meet a few times a year to discuss issues of concern to small states. In 2012 it held its inaugural Conference on Small States in New York. FOSS also meets in Geneva.

The SIDS label thus remains somewhat ambiguous and the exceptionalism it generates is not guaranteed. There is nothing natural or neutral about the SIDS category; it has been created to give voice to the political concerns of a specific group of states. If SIDS had not actively participated in the process the label would in all likelihood not exist in the UN, let alone elsewhere. In turn, the SIDS category has provided successive generations of diplomats a platform on the world stage. And, by drawing attention to their vulnerable condition, particularly in climate change discussions, they have shaped global deliberations and set precedents that others have followed.

In the WTO the SVEs is an intermediary grouping, but its formation was seen by SVE diplomats as a huge victory nonetheless. As a former SIDS diplomat who later worked at the WTO asserted ${ }^{99}$ :

This meant the small states had a home. They had a place. They had an anchor to WTO discussions because the report of this committee would then go to what is the highest decision-making body in the WTO which is the General Council. So, from an institutional perspective, I mean I think that was really, really important ... Every single WTO decision since then has incorporated and recognised the legitimacy of having a dedicated discussion of small vulnerable economies. So, we've never had to go in there and renegotiate. We've never had to reaffirm the importance of keeping it there. It is something which is now ingrained in the DNA of the WTO.

98 Goulding (2016); Fry (2016), p. 107

${ }^{99}$ Author interview, March 2017 
The SVEs meet regularly, have focal points for items on the WTO agenda, and co-ordinate positions. They have succeeded in gaining agreement through the General Council that they be allowed to use regional bodies for notifications. This may seem like a minor amendment to the processes but the principle at the WTO is that unless countries are bound within a single economic community, like the EU, only member states can have a voice in deliberations. But many SVEs find the costs of maintaining missions in Geneva too prohibitive. This agreement allowed them to be represented by regional bodies like the Organisation of Eastern Caribbean States or the Pacific Islands Forum who can act as an intermediary and representative at various headquarters.

The upshot of these and numerous other examples is that during the 2000s, SVEs, led by active countries like Mauritius, Barbados and Jamaica, were able to carve out a place within the WTO. Not only did they show that SVEs had a voice and could fight their corner, but they came to be seen as a constructive player in the WTO system, leading to occasions when their representatives were invited to Green Room meetings when compromises were thrashed out by key players. For our purposes, the important point is that by competently performing vulnerability SVEs have influenced IOs outside the UN system and climate negotiations.

That participation is not universal. Its significance is underscored by (the lack of) SIDS involvement in WIPO. Traditionally SIDS and SVEs may have intellectual property concerns and, like many middle powers with few direct interests, they rarely engage. In the last decade WIPO has taken on a development agenda and the Secretariat has spent considerable effort seeking to involve members who are not active participants. In general, IP issues are seen by many SIDS and SVEs to be too peripheral, and too technical. As a result, SIDS and SVEs have not embedded themselves into the fabric of WIPO's processes in the same way they have in other IOs. The key point, from our perspective, is that while we have placed considerable emphasis on the importance of institutional mechanisms, they are not sufficient in and of themselves to drive norm emergence and diffusion.

This example highlights the well-documented capacity problems that SIDS and SVEs have in participating in IOs. It is virtually impossible for them to cultivate competent performances 
if they are not present. ${ }^{100}$ Most SIDS and SVEs have a mission in New York but they are represented in smaller numbers in Geneva where missions work on multiple IOs and may also be accredited to other European states. To overcome some of these difficulties the Commonwealth has established a Small States office in Geneva. The office provides subsidised facilities for small state missions and some expert staff who can assist in understanding the common problems they must discuss. But the core issue remains. Small teams mean that SIDS and SVEs tend to focus on those issues and IOs that are of primary importance and where they can have the most impact (i.e. the WTO).

The capacity problems that impede the active participation of SIDS has recently been recognised by the 2012 establishment by the UNHRC of a Voluntary Technical Assistance Trust Fund to Support the Participation of Least Developed Countries and Small Island Developing States in the work of the Human Rights Council (resolution 19/26). The fact that developing countries require concessions and additional support is a well-established norm in IOs since the Second World War. By placing SIDS in the same category, the LDCs/SIDS Trust Fund-administered by the OHCHR and funded by 21 countries $^{101}$ - provides essential funding, capacity building, and training to support participation in the processes of the UNHRC. Further support for this initiative was provided by resolution $34 / 40$, passed in 2017, which was co-sponsored by 120 states, making it the second most sponsored resolution since the establishment of the HRC in $2006 .{ }^{102}$ If nothing else, this illustrates how well accepted the label and the unique vulnerability of smallness have become.

\section{Conclusion}

By combining rhetorical action, collaboration and active participation, the states we now call SIDS and SVEs have acted as norm entrepreneurs and in doing so created distinct labels and associated groupings across multiple IOs. The key to the creation and diffusion of this constitutive norm is the competent performance of vulnerability, aided by an existing,

\footnotetext{
100 Corbett and Connell 2015

${ }^{101}$ Houel 2017

102 Houel 2017
} 
advantageous regime of norms ${ }^{103}$, including the right to development and the sovereign equality of states, and the disproportionate impact of climate change. To be sure, the process has been ad-hoc in nature, which, when combined with the institutional rules of IOs, explains the variation in terms of both reception, nomenclature and definition. But our empirical description reveals that these labels share more than a family resemblance; the core norm of 'differentiated development' and the way they have been diffused are the same even if the outcome, be it the name of the label and its membership, varies.

Based on this finding we add to recent scholarship ${ }^{104}$ on the existence of small states under anarchy by illustrating that their survival is not merely a by-product of an international regime of norms; SIDS and SVEs are actors in their own right whose participation in the processes of IOs has brought them recognition and benefits from the international system. We also add to the literature on the creative diplomacy of small states by showing that the well-documented strategies of European states can also be adapted for SIDS and SVEs, even if they do not seek them same 'status' (de Carvalho and Neumann 2015). We also extend the literature on resilience by highlighting how vulnerability functions as an adaptive strategy in its own right. Being recognized as a distinct group defined by its structural weaknesses has ostensibly entrenched SIDS and SVEs lowly status, but it has also brought benefits. Indeed, in the context of climate change ${ }^{105}$, those facing extinction may find that highlighting their vulnerability secures survival.

\footnotetext{
98. Alensina and Spolaore (2005)

104 Sharman $(2015,2017)$

105 Milla Emilia Vaha, 'Drowning under: Small island states and the right to exist,' Journal of International Political Theory, 11:2 (2015), pp. 206-23; Kim Angell, Kim, 'New territorial rights for sinking island states,' European Journal of Political Theory https://doi.org/10.1177/1474885117741748 (2017)
} 